\title{
Hızlandırılmış UV Yaşlandırma ile Odunda Meydana Gelen Renk, FTIR ve Mikroskobik Değişimlerin Belirlenmesi
}

\author{
Eser SÖZEN ${ }^{1^{*}}$ \\ Bartın Üniversitesi, Orman Fakültesi, Orman Endüstri Mühendisliği Bölümü, 74100, Bartın
}

\section{Öz}

Yağmur, güneș, rüzgâr gibi doğal şartlar ahşap malzemenin fiziksel, kimyasal ve mekanik özelliklerinde değişimlere neden olmaktadır. Bu değişimler çoğunlukla olumsuz olarak nitelendirilmektedir. Ancak, bazı durumlarda bu olumsuz değişimler doğallığı ifade etmesi veya bir sonraki işlem için gerekli olmasında dolayı tercih edilebilmektedir. Bazı mobilya ve iç mekan tasarımlarında eskitme olarak nitelendirilen ahşaplar özellikle tercih edilmektedir. Bu çalıșmada, kayın (Fagus orientalis L.) odununda hızlandırılmıș UV yaşlandırma testi sonrasında renk değişimi, lignin oranı ve hücre çeperinde meydana gelen değişimler incelenmiştir. Renk ölçümü, 500 saatlik UV yaşlandırma testi öncesinde ve sonrasında yapılmıştır. FTIR analizi sonucunda $945-1132 \mathrm{~cm}^{-1}$ dalga boyu değerleri arasındaki hemiselüloz ve lignin oranında kontrol örneklerine göre \%14,78 azalma meydana geldiği görülmüştür. Hücre çeperinde meydana gelen değişimler SEM analizleri ile enine kesit ve teğette ayrı ayrı incelenmiştir. Enine kesitte UV sonrası kontrol örneklerine göre belirgin çatlakların oluştuğu görülmüştür. Boyuna yönde ise paranşim hücrelerinde dağılmaların olduğu saptanmıştır.

Anahtar Kelimeler: Hızlandırılmış UV yaşlandırma, FTIR, lignin, SEM, Hücre çeperi.

\section{Determination of Color, FTIR and Microscopic Changes in Wood by Accelerated UV Aging}

\begin{abstract}
Natural conditions such as rain, sun, wind cause changes in the physical, chemical and mechanical properties of the wood material. These changes are often described as negative. However, in some cases, these negative changes may be preferred because they express naturalness or are necessary for the next process. In some furniture and interior designs, woods described as aging are especially preferred. In this study, colour change, lignin ratio and changes in cell wall after accelerated UV aging test in beech (Fagus orientalis L.) wood were investigated. Colour measurement was done before and after 500 hours of UV aging test. As a result of FTIR analysis, it was seen that there was a decrease of $14.78 \%$ in the ratio of hemicellulose and lignin between the wavelength values of $945-1132 \mathrm{~cm}^{-1}$ compared to the control samples. Changes in the cell wall were examined separately in cross section and tangent by SEM analysis. Significant cracks were observed in the cross section compared to the control samples in after UV. It was determined that there are dispersions in the parenchyma cells in the longitudinal direction.
\end{abstract}

Keywords: Accelerated UV aging, FTIR, lignin, SEM, Cell wall. 


\section{Giriş}

Sürdürülebilir kalkınmanın sağlanmasında odun kökenli (lignoselülozik) yenilenebilir doğal malzemelerin kullanılması büyük bir katkı sağlamaktadır. Ekolojik yükü (kimyasal maddeleri) azaltmak için, ahşap yapıların yüzeyi genellikle işlenmemiş olarak bırakılır. Geleneksel iç tasarım unsurlarının yanında, işlem görmemiş ahşabın dış mekanda kullanımı da artmaktadır. Çağdaş tasarım trendleri arasında, dış ortam koşullarında yüzeyi grileşen ahşabın tercih edildiği görülmektedir (Lesar vd., 2016).

Odunun ana bileşenlerini oluşturan selüloz, hemiselüloz ve lignindeki organik bileşenler hava koşullarına tepki verir. Fotodegradasyon odunun çevresel etkilerden dolayı bozunmasında en hızlı ve en güçlü gerçekleşen olaydır (Feist ve Hon 1984; Hon ve Chang 1984). Özellikle lignin, ultraviyole (UV) 1şığın neden olduğu fotodegradasyona en duyarlı ahşap bileşenidir (Pandey, 2005; Reinprecht, 2016). Lignin, genellikle koniferil, kumaril ve sinapil olmak üzere üç farklı alkolden oluşan, son derece karmaşık üç boyutlu bir polimerdir (Anulika vd., 2016). Bu üç alkolün alt dallarını farklı oranlarda H (p-hidroksifenil), G (Guayasil), ve S (Siringil) fenil propan birimleri oluşturur. Bu aromatik biyopolimer, UV radyasyonunu güçlü bir şekilde absorbe eder (Hon ve Minemura 2001). FTIR spektrumunda 1506-1510 cm-1 de lignin bileşenlerini karakterizasyonunu (Zor vd. 2019) ve $1242 \mathrm{~cm}^{-1}$ de lignin ile yeterli bağ yapmasından kaynaklı yoğunluğunda artış gözlemlendiği belirtilmiştir (Zor ve Can 2021). Odundaki hücre duvarı, farklı periyotlarda hücre farklılaşmasıyla oluşan birkaç tabakalı kompozit bir yapıya sahiptir. Hücre duvarı son boyutuna ulaştıktan sonra, mekanik olarak kritik öneme sahip üç farklı alt katmandan oluşan sekonder çeper (S1, S2 ve S3) meydana gelir (Plomion vd., 2001). Odunun bileşenleri, özellikle lignin kısa dalga boyunda (295 ila $400 \mathrm{~nm}$ arası) 1şığı absorbe edebilir. Lignin, odunun renginden sorumlu olan kromoforik yapıları (aromatik bileşikleri) içeren, rastgele dizilmiş, karmaşık bir polimerdir $(1,38)$. Odun bileşenleri çeşitli fonksiyonel gruplar ve bağlantılar nedeniyle fotodegradasyon karşısında aynı hassasiyete sahip değildir. Örneğin ligninde en fazla $\beta-\mathrm{O}-4$ bağlarının yanında $5-5 \beta-5, \beta-1, \alpha-\mathrm{O}-4$ ve 4-O-5 bağları da bulunmaktadır (Feist ve Hon 1984). Ligninde bulunan farklı moleküller ve arasındaki bağlar Şekil 1'de gösterilmiştir.

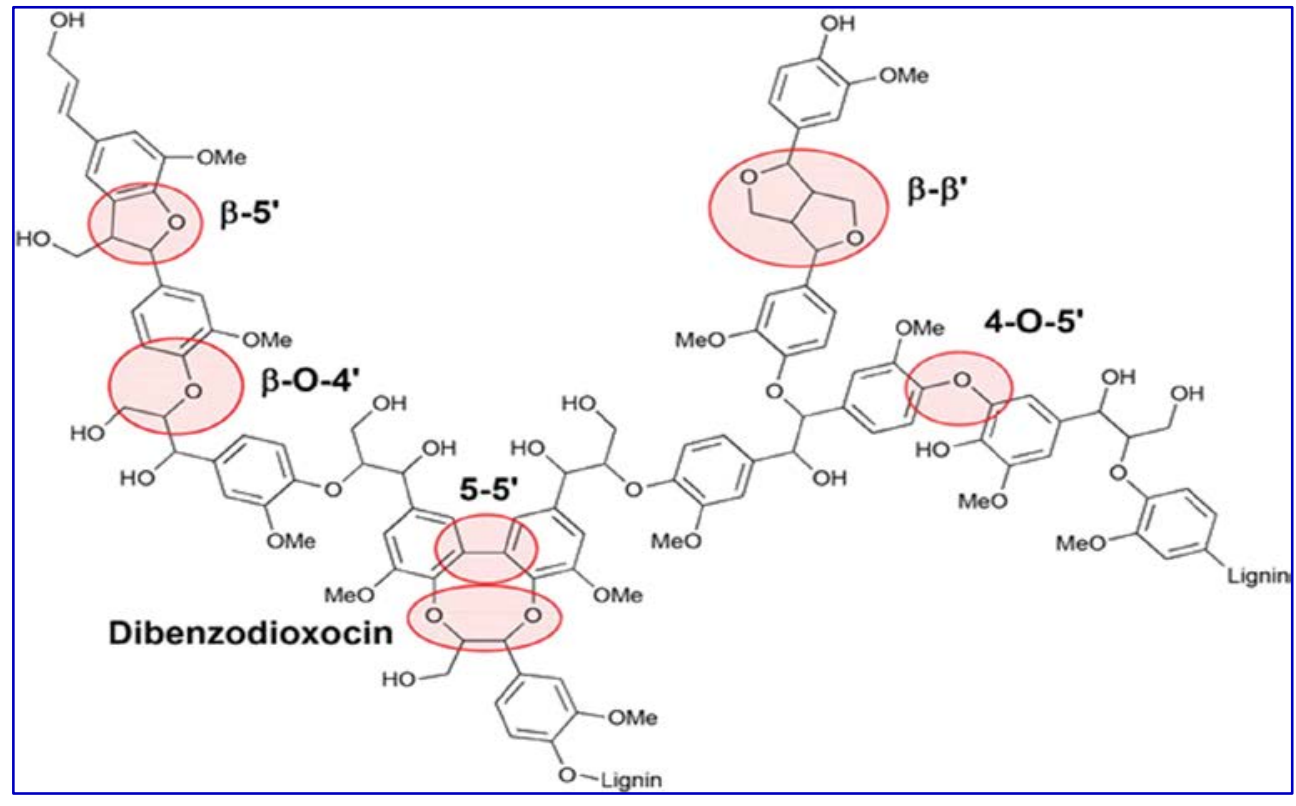

Şekil 1. Lignindeki farklı moleküller arası bağlar (Feist ve Hon 1984).

Odunda kimyasal bozunma sürecinin oluşması ve izlenmesi üzerine birçok çalışma gerçekleştirilmiştir (Timar vd., 2016; Nemeth vd., 2016; Cogulet vd., 2016; Liu vd., 2017). Odunda gerçekleşen fotodegradasyonu daha iyi anlamak için iki ana unsur üzerinde çalışılmıştır. Bunlar (1) CIELAB renk skalası ve (2) FTIR/FTIR-ATR analizleridir. CIELAB renk skalası, ligninin bozunması ve kromofor oluşumuna bağlı olarak odundaki renk değişikliklerini belirlemek için kullanılır (Tolvaj ve Faix 1995). Yüzeyden yapılan FTIR (Fourier Transform Infrared Spectroscopy) analizleri ise fotodegradasyon nedeniyle oluşan kimyasal modifikasyonlar hakkında bilgi verir (Colom vd., 2003; Pandey ve Pitman 2003; Teacă vd., 2013). FTIR analizleri, kimyasal mekanizmaların incelenmesi ve degradasyonun derecesini belirlemek için birçok yazar tarafından kullanılmış faydalı bir tekniktir. Lignin veya holoselüloz gibi odun bileşenlerinin değişimleri bu teknikle izlenebilir. Örneğin, saf bir ligninin pik noktası $1510 \mathrm{~cm}^{-1}$ 'de bulunabilir. Ligninin aromatik yapısındaki titreşimi $\mathrm{C}=\mathrm{C}$ bağlarıyla sağlanır (Anderson vd., 1991). 
Liu vd., (2017) ve Reinprecht vd., (2018) 10 farklı tropik ağacın yaşlandırma testi sırasında yüzeyinde meydana gelen değişimleri incelemişlerdir. Çalışma soncunda elde edilen sonuçlara göre, odundan sızan ekstraktif

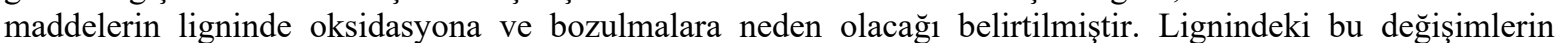
miktarlarının odun türüne göre de farklılık gösterdiği vurgulanmıştır. Gupta vd., (2011) üst yüzey işlemi uygulanan ahşap materyallerin servis ömrünü belirlemek için FTIR analizlerinden faydalanmıştır. Üst yüzey işlemlerinde en önemli amaçlardan birisi de zararlı kimyasalları mümkün olduğu derecede az kullanmaktır (Singh ve Singh 2012). Bu nedenle yaşlandırma işlemi sırasında masif odundaki değişimlerin bilinmesi ve izlenmesi önemli bilgiler sağlamaktadır (Brischke ve Rapp 2008). Bu çalışmada, UV yaşlandırma işlemine tabi tutulan kayın odunlarında meydana gelen renk değişimleri incelenmiştir. FTIR analizleriyle odunun kimyasal bağ yapısındaki değişimler belirlenmiştir. Gerçekleştirilen SEM analizleri ile enine ve boyuna yönlerde meydana gelen değişimler ortaya konmuştur.

\section{Materyal ve Metot}

Çalışmada kayın odunu (Fagus orientalis L.) kullanılmıştır. UV yaşlandırma testleri için örnekler 150mm uzunluk, $3 \mathrm{~mm}$ kalınlıkta daire testere yardımıyla kesilmiştir. Örneklerin genişlikleri farklılık göstermektedir. Toplamda 18 adet örnek hazırlanmış ve numaralandırılmıştır. Hızlandırılmış UV yaşlandırma testleri Q-LAB Corporation (USA) firması tarafindan üretilen QUV Accelerated Weathering Tester isimli cihaz kullanılarak gerçekleştirilmiştir. Test süreci ASTM G154 (2006) standartlarında belirtilen şartlara uygun olarak yürütülmüştür. Örnekler, Hızlandırılmış UV yaşlandırma cihazında 20 dakika su sprey, 4 saat UV yaşlandırma ortam koşullarında (0,67 lux 1şık şiddeti, 20 dakika su sprey, 4 saat UV ve $50^{\circ} \mathrm{C}$ ortam sıcaklığ 1$)$ ve UV - A 340 florasan lambalarının etkisi altında 500 saat UV yaşlandırma etkilerine maruz bırakılmıştır.

Renk ölçümlerinde ISO 7724 (1984) standartlarında belirtilen prosedür takip edilmiş ve Konica Minolta CD-600 marka renk ölçüm cihazı kullanılmıştır. Her örnek için test öncesinde ve sonrasında iki farklı noktadan renk ölçümü gerçekleştirilmiş ve ortalaması alınmıştır. Daha sonra 18 örneğe ait ortalamalar üzerinden UV öncesi ve sonrası renk değişimleri belirlenmiştir. Renk ölçümlerinde aşağıdaki formüller kullanılmıştır.

$$
\begin{aligned}
& \Delta \mathrm{L}^{*}=\mathrm{L}_{\mathrm{l}}{ }^{*}-\mathrm{L}_{\mathrm{f}}{ }^{*} \\
& \Delta \mathrm{a}^{*}=\mathrm{a}_{\mathrm{l}}{ }^{*}-\mathrm{a}_{\mathrm{f}}{ }^{*} \\
& \Delta \mathrm{b}^{*}=\mathrm{b}_{\mathrm{l}}{ }^{*}-\mathrm{b}_{\mathrm{f}}{ }^{*} \\
& \Delta \mathrm{E}^{*}=\sqrt{\left(\Delta \mathrm{L}^{* 2}+\Delta \mathrm{a}^{* 2}+\Delta \mathrm{b}^{* 2}\right)}
\end{aligned}
$$

$\Delta \mathrm{L}^{*}, \Delta \mathrm{a}^{*}$ ve $\Delta \mathrm{b}^{*}$ başlangıç (f) ve değişik zaman aralıklarında (l) meydana gelen renk değişikliklerini belirtmektedir. $\Delta \mathrm{E}^{*}$ toplam renk değişimini ifade etmektedir. Düşük $\Delta \mathrm{E}^{*}$ değeri renk değişikliğini veya renk stabilitesini göstermektedir. CIELab (Commission Interational de i’Eclairage) sistemi üç değişkenden oluşmaktadır (ISO 7724). L*: Işık stabilitesi, $a^{*}$ ve b* kromotografik koordinatları ifade etmektedir. +a* kırmızı, -a* yeşil, +b* sarı, -b* mavi renk için kullanılmaktadır (Can, 2018).

FTIR (Fouirer Transform Infrared Spektrofotometre-Fourier Dönüşüm Kızılötesi Spektroskopi) analizleri Perkin Elmer Spectrum 100 marka ve modelli analiz cihazı ile ATR Diamond/ZnSe aperatı kullanılarak gerçekleştirilmiştir. UV yaşlandırma öncesi ve sonrası yüzeyden yapılan ölçümler karşılaştırılmıştır. Örneklerin spectrası $4 \mathrm{~cm}^{-1}$ çözünürlükte ve 800-3200 tarama aralığında alınmıştır.

Çalışmada kullanılan örneklerin test öncesi ve sonrası morfolojik yapısındaki değişim Taramalı Elektron Mikroskobu (SEM) Phillips Electroscan 2020 marka ve modelli analiz cihazıyla gerçekleştirilmiştir. Analiz, 5kV hızla arttırılan azot ortamında gerçekleştirilmiştir. Örneklerin yüzeyleri iletkenliğin arttırılması için Denton püskürtme cihazı kullanılarak altın ile kaplanmıştır. Analizlerinde kontrol ve UV yaşlandırma sonrası örneklerin enine ve teğet kesitlerinden alınan örnekler karşılaştırılmıştır.

\section{Bulgular ve Tartışma}

\subsection{Renk Değişimi}

Çalışmada kullanılan örnekler ve örneklere ait UV yaşlandırma testleri öncesi ve uygulanan 500 saat UV sonrası görünümler Şekil 2 ve şekil 3 'te sırasıyla gösterilmiştir. 


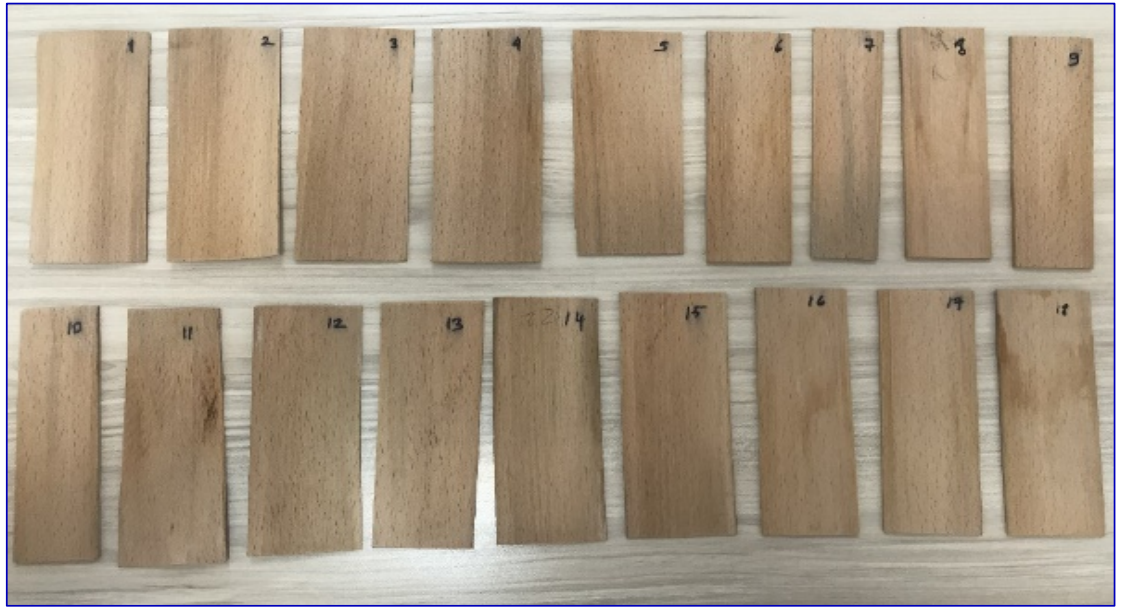

Şekil 2. Örneklerin UV yaşlandırma testi öncesi görünümü.

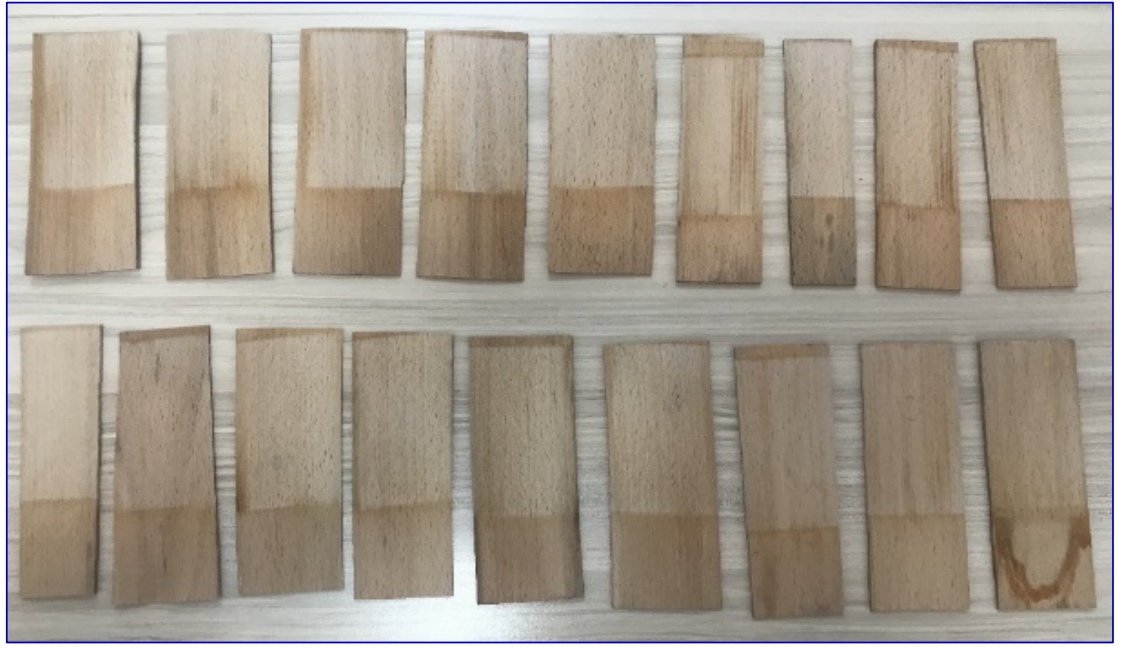

Şekil 3. Örneklerin 500 saat UV yaşlandırma testi sonrasındaki görünümü.

UV yaşlandırma testi öncesinde ve sonrasında örneklerin $\mathrm{L}^{*}$, $\mathrm{a}^{*}$ ve $\mathrm{b}^{*}$ değerleri belirlenmiştir ve ortalama değerleri Tablo 1'de gösterilmiştir. Elde edilen veriler SPSS paket programında tek yönlü varyans analizi (ANOVA) ile değerlendirilmiştir. İstatistiki olarak kontrol ve UV sonrası ölçümler arasında anlamlı fark olduğu belirlenmiştir.

Tablo 1. UV yaşlandırma testi öncesinde (kontrol) ve sonrasında örneklerin L*, a* ve b* değerleri.

\begin{tabular}{lccc}
\hline Örnek & $\mathbf{L}^{*}$ & $\mathbf{a}^{*}$ & $\mathbf{b}^{*}$ \\
\hline Kontrol & 60,58 & 13,52 & 22,39 \\
UV sonrası & 70,49 & 8,04 & 15,47 \\
$\Delta\left(\mathrm{L}^{*}, \mathrm{a}^{*}, \mathrm{~b}^{*}\right)$ değerleri & $-9,91$ & 5,47 & 6,92 \\
Toplam renk değişimi $(\Delta \mathrm{E})$ & & 13,26 & \\
\hline
\end{tabular}

Gerçekleştirilen ölçümlerde $\Delta \mathrm{L}$ değeri -9,91 olarak ölçülmüştür. Odunun UV yaşlandırma testleri sırasında ortam şartları (süre, sıcaklık, 1şık şiddeti ve süresi) ve odun türü değişimler üzerinde etkili olmaktadır. Fidan vd. (2018) ladin ve kayın odunlarını 168, 366, 504 ve 672 UV yaşlandırma testine tabi tutmuş, sonrasında renk ve pürüzlülük özelliklerini incelemişlerdir. Çalışma sonucunda ağaç türünün ve yaşlandırma süresinin renk değişimi üzerinde istatistiksel olarak anlamlı farklılıklara yol açtığı bildirilmiştir. Yine aynı çalışmada $\Delta \mathrm{L}$ değeri 168 saat sonunda 21,23 iken, 366 saat sonunda -4,95'e düşmüş, yaşlandırma süresi 504 saate çıkarıldığında ise $\Delta \mathrm{L}$ değeri 
16,68'e çıkmıştır. Gerçekleştirilen çalışma Fidan vd., (2018)'in 504 saat yaşlandırma uygulandığında elde edilen $\Delta \mathrm{L}^{*}$ değeriyle karşılaştırıldığında 6,67’lik bir $\Delta \mathrm{L}^{*}$ farkı bulunmaktadır. Bu farkın büyük oranda UV yaşlandırma ortamındaki 1şık şiddetinden ve sıcaklık farklarından kaynaklandığı düşünülmektedir. Gerçekleştirilen çalışmalarda yüksek sıcaklıkların (Derbyshire vd., 1997), yüksek rutubet içeriklerinin (Turkulin vd., 2004) ve seyreltilmiş asitlerin (Hon, 2007) odunda renk değişimlerine neden olabileceği bildirilmiştir.

\subsection{FTIR Analizi}

Çalışma kapsamında UV yaşlandırma işlemine tabi tutulan kayın örneklerin teğet kesitlerinde test öncesi ve sonrası FTIR (Fourier-Transform Infrared Spectroscopy) analizleri gerçekleştirilmiştir. Tablo 4'te UV yaşlandırma testi öncesi (kontrol) ve sonrası FTIR analizleri gösterilmiştir.

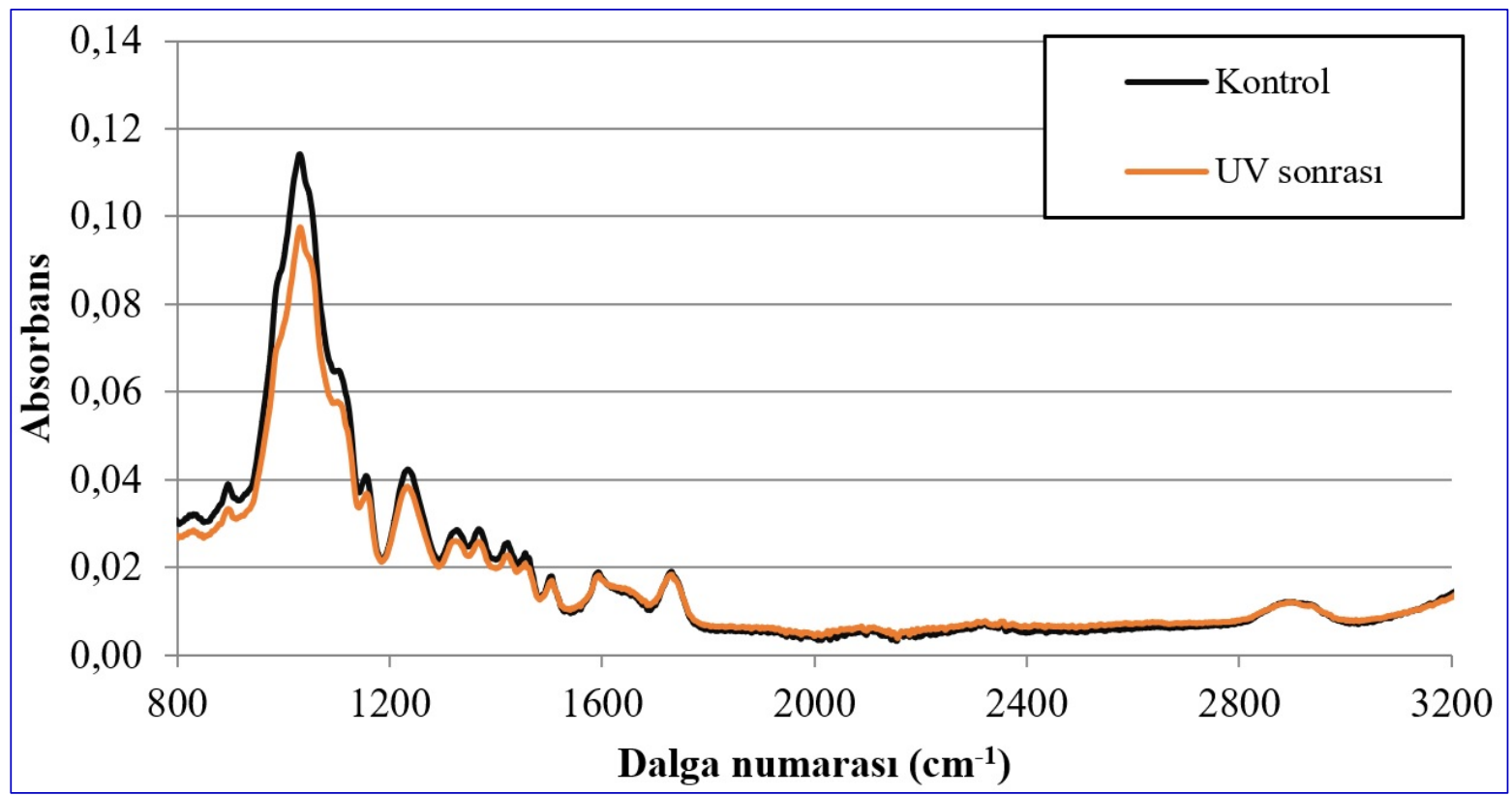

Şekil 4. UV yaşlandırma testi öncesi ve sonrası FTIR analizi.

FTIR analizi, maksimum $5 \mu \mathrm{m}$ derinlik penetrasyonuna sahiptir. Bu derinlik, UV sonrası numunelerin en çok bozulmuş olan gümüş tabakasına karşılık gelir. Odunun FTIR spektrumlarının temel modelleri olan 3300-4000 $\mathrm{cm}^{-1}$ de güçlü bir geniş O-H gerilim absorpsiyon bandı ve 2800-3000 $\mathrm{cm}^{-1}$ de bir C-H gerilimi bulunmaktadır (Müller vd. 2003; Pandey ve Pitman 2003; Ganne-Chédeville vd., 2012). Odunun renginin oluşmasında en etkili madde, hücre çeperinde bulunan lignindir. Bunun yanında ekstraktif maddeler de farklı renklerin oluşmasında etkili olmaktadır. Ligninin temelini oluşturan koniferil, kumaril ve sinapil alkollerinin alt dalları olan phidroksifenil (H), Guayasil (G) ve Siringil (S) fenil propan aromatik birimler UV radyasyonunu güçlü bir şekilde absorbe eder (Hon ve Minemura 2001). Çalışma kapsamında 945-1132 dalga numaraları arasında kontrol örneklerine göre UV yaşlandırma sonrasında \%14,78'lik bir azalma görülmüştür. Maksimum pik 1031 dalga numarasında kaydedilmiştir. Ganne-Chédeville vd., (2012) 1031 dalga boyunda selüloz ve hemiselülozda C-O titreşimlerinin olduğunu belirtmişlerdir. Yine \%14,78'lik azalmayı oluşturan dalga boyu içerisinde yer alan 1104 $\mathrm{cm}^{-1}$ numaralı pik noktasında, aromatik iskelet titreşimleri ve C-O gerilmeleri görülmektedir (Müller vd. 2003). Can ve Sivrikaya (2019) $1595^{-1}$ dalga numarasında güçlü aromatik C-O bağlarının bulunduğunu bildirmiştir. Bu pik değerlerinde değişimlerin gözlenmemesi bağların güçlü olması veya uygulan yaşlandırma şartlarının yetersiz olmasından kaynaklanmıştır. Aromatik yapılardaki değişimlerin renk değişimi üzerinde etkili olduğu ve ölçülen renk değerlerindeki farklılıkların oluşmasında etkili olduğu düşünülmektedir.

\subsection{Taramalı Elektron Mikroskobu-SEM (Scanning Electron Microscope) Analizi}

Çalışma kapsamında UV yaşlandırma öncesi ve sonrasında örneklerin enine ve teğet kesitlerinde Taramalı Elektron Mikroskobu-SEM (Scanning Electron Microscope) ile incelenmiştir. Kesitler incelenirken kontrol örneklerinde spesifik özellikler gösteren kısımları baz alınmış, UV yaşlandırma sonrası bu alanlarda meydana gelen değişimler karşılaştırılmıştır. Mikroskopik değişimler boyuna paranşim hücrelerinde daha belirgin olarak görülmektedir. Kontrol örneklerinin teğet kısımlarında yer alan paranşim hücreleri daha belirgin ve geçit büyükleri daha büyük olarak görülmektedir (Şekil 5-a ve b). UV yaşlandırma sonrasında ise geçitlerde büyük 
oranda daralmaların oluştuğu belirlenmiştir. (Şekil 5-c ve d). Bu durumun oluşmasında uygulan su püskürtmeye bağlı olarak çeperlerin lif doygunluk noktasına (LDN'ye) ulaşması, sıcaklık ile suyun uzaklaşması ve bunun tekrarlanarak uygulanması etkili olmuştur. Şekil 5 ve 6'da UV yaşlandırma öncesinde ve sonrasında sırasıyla enine ve teğet kesitten alınan SEM görüntüleri verilmiştir.

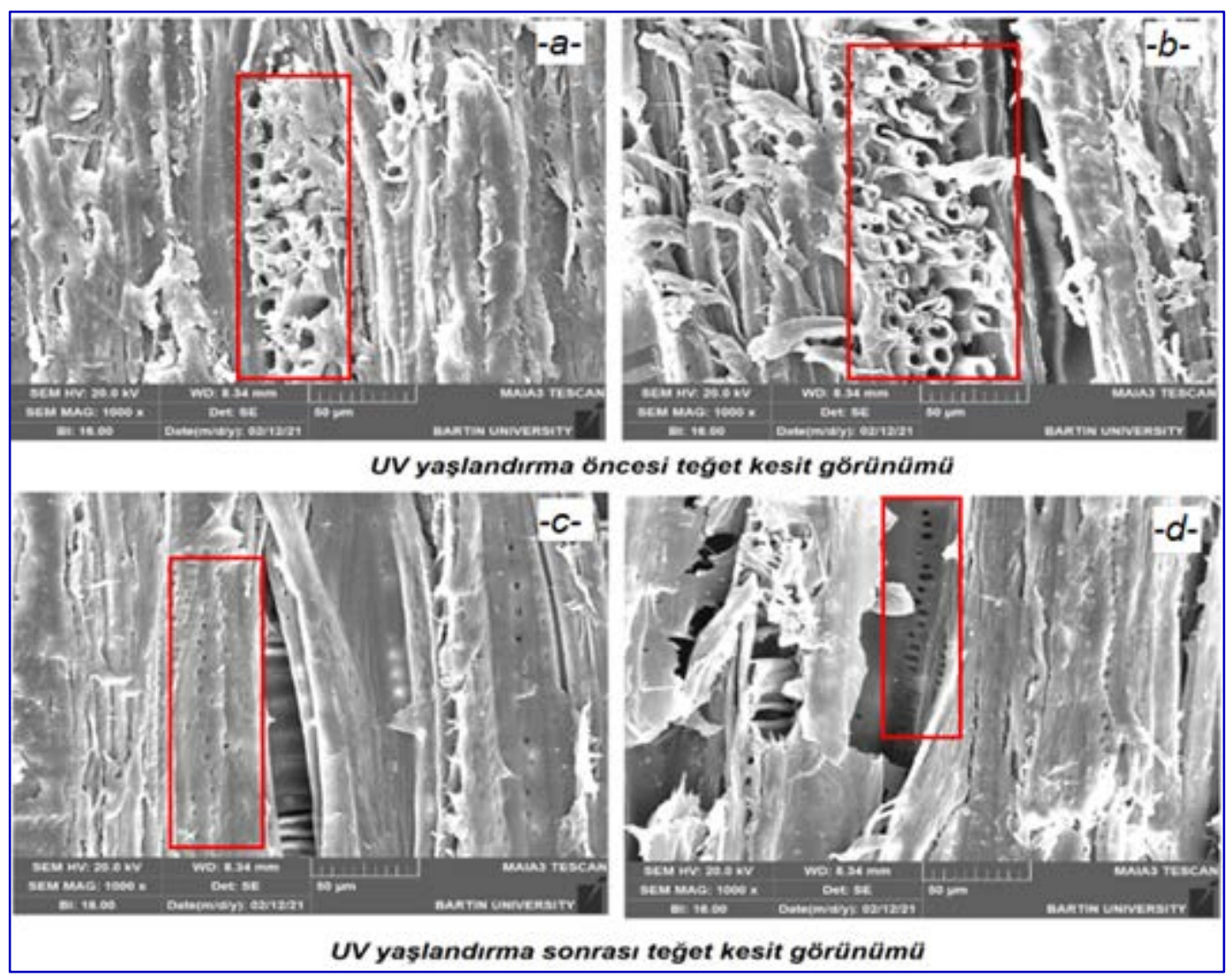

Şekil 5. UV yaşlandırma öncesinde (a-b) ve sonrasında (c-d) teğet kesit görünümü. 


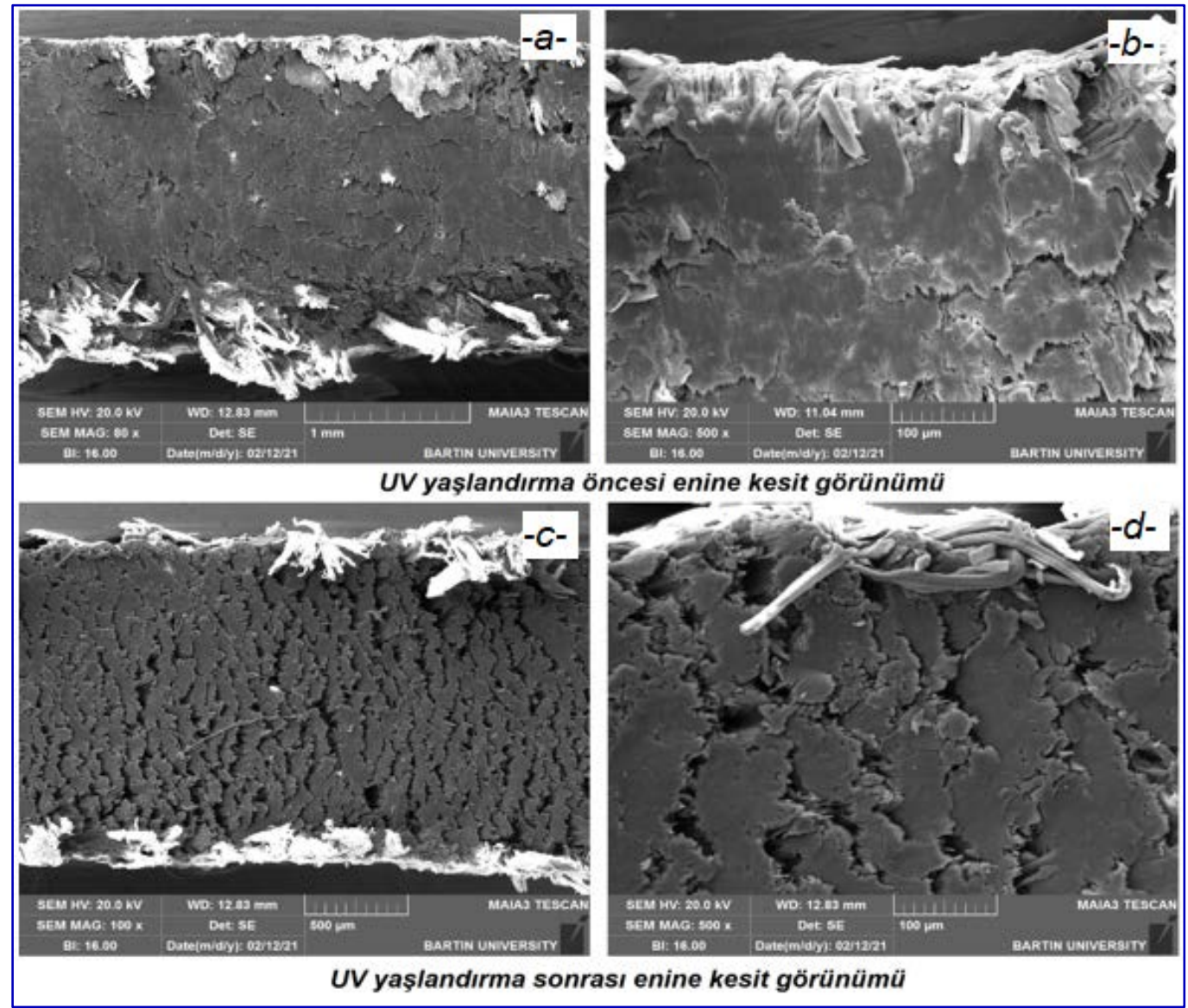

Şekil 6. UV yaşlandırma öncesinde (a-b) ve sonrasında (c-d) enine kesit görünümü.

Örneklerin UV yaşlandırma öncesinde ve sonrasında enine kesit görünümleri incelendiğinde 500 saatlik süre içinde örneklerin su alıp-vermesine (adsorpsiyon-desorpsiyon) bağlı olarak yarılmaların olduğu görülmüştür. UV yaşlandırma işlemi sadece teğet kesite uygulandığı için bu oluşumların yüzeylere püskürtülen sulardan kaynaklandığ tespit edilmiştir. Şekil 6-c'de görüldüğü gibi enine kesit boyunca homojen yarılmaların olduğu söylenebilir. Bu durumun kayın odununun anatomik yapısından kaynakladığı söylenebilir. Çünkü kayın odunu kavak, söğüt gibi dağınık trahe özelliği gösteren ağaç grubu içerinde yer almaktadır. Bu durum hücre çeperleri arasındaki daralmalara bağlı olarak homojen yarılmaların oluşmasında etkili olmuştur.

\section{Sonuç ve Öneriler}

Odunun doğal şartlara dayanımının belirlendiği doğal veya yapay yaşlandırma işlemleri odunun renk, parlaklık, kimyasal bileşiminde farklıklara yol açabilmektedir. Yaşlandırma işlemleri estetik görünüm veya farklı proseslerde ön işlem olarak da uygulanabilmektedir. Özellikle UV absorblama kabiliyeti bulunan aromatik yapılardan faydalanılarak kimyasal bağların zayıflatılması, oduna uygulanacak bazı proseslerde kimyasalların etkinliklerini arttırmaktadır.

Kayın odununa uygulanan 500 saatlik UV yaşlandırma sonucunda renk değişimlerinde anlamlı farklılıkların oluştuğu belirlenmiştir. Renk değişiminde odunun ana bileşenlerinden olan ligninde buluna kromofor gruplarının UV absoblama özelliğinden kaynaklandığı FTIR analizleri sonuçlarıyla doğrulanmıştır. $1104 \mathrm{~cm}^{-1}$ dalga boyundaki değişimler aramotik gruplardaki azalmaları kanıtlamaktadır. SEM analizlerinde elde edilen sonuçlar ışı̆̆ında UV yaşlandırma işlemlerinde odunun adsorpsiyon-desorpsiyon davranışları odunda daralmalara (gerilmelere) neden olmaktadır. Bu durumunda odunun özellikle enine kesitinde çatlamalara neden olduğu görülmüştür. Diğer taraftan teğet kesitte bulunan paranşim hücrelerindeki geçitlerde daralmaların oluştuğu açıkça görülmüştür. Sonuç olarak UV yaşlandırma işlemleri odunda renk ve anatomik yapısında değişikliklere yol açmaktadır. Odunun kullanım amacına bağlı olarak, farklı sonuçlara ulaşmak için UV işlemlerinin ön işlem olarak uygulanabileceği görülmüştür. Gerçekleştirilecek yeni çalışmalarda, sadece UV ışınlarının farklı şiddet 
ve sürelerde farklı ağaç malzemelerde oluşturduğu etkiler ve bu etkilerin avantaj olarak kullanılabileceği alanlar, sektörler değerlendirilebilir.

\section{Kaynaklar}

1. Anderson, E. L., Pawlak, Z., Owen, N. L., Feist, W. C. (1991). Infrared studies of wood weathering. Part I: Softwoods. Applied spectroscopy, 45(4), 641-647.

2. Anulika, N. P., Ignatius, E. O., Raymond, E. S., Osasere, O. I., Abiola, A. H. (2016). The chemistry of natural product: Plant secondary metabolites. Int. J. Technol. Enhanc. Emerg. Eng. Res, 4, 1-8.

3. Brischke, C., Rapp, A. O. (2008). Dose-response relationships between wood moisture content, wood temperature and fungal decay determined for 23 European field test sites. Wood Science and Technology, 42(6), 507.

4. Can, A. (2018). Su İtici Maddeler İle Kombine Edilmiş Bazı Emprenye Maddelerinin Performansının İncelenmesi. Doktora Tezi, Bartın Üniversitesi, Fen Bilimleri Enstitüsü, Orman Endüstri Mühendisliği Anabilim Dalı, Bartın, $176 \mathrm{~s}$.

5. Can, A., Sivrikaya, H. (2019). Surface characterization of wood treated with boron compounds combined with water repellents. Color Research \& Application, 44(3), 462-472.

6. Cogulet, A., Blanchet, P., Landry, V. (2016). Wood degradation under UV irradiation: A lignin characterization. Journal of Photochemistry and Photobiology B: Biology, 158, 184-191.

7. Colom, X., Carrillo, F., Nogués, F., Garriga, P. (2003). Structural analysis of photodegraded wood by means of FTIR spectroscopy. Polymer degradation and stability, 80(3), 543-549.

8. Derbyshire, H., Miller, E. R., Turkulin, H. (1997). Investigations into the photodegradation of wood using microtensile testing. Holz als Roh-und Werkstoff, 55(5), 287-291.

9. Feist, W. C., Hon, D. N. S. (1984). Chemistry of Weathering and Protection, The Chemistry of Solid Wood, American Chemical Society 1984, pp. 401-451.

10. Fidan, M. S., Ertaş, M., Kaya, S., Karademir, A. (2018). Hızlandırılmış UV yaşlandırma etkisine maruz bırakılan kayın ve ladin odunlarının yüzey pürüzlülüğü ve renk ölçümü üzerine etkileri. İklim Değişikliği ve Çevre, 4(2), 1-9.

11. Ganne-Chédeville, C., Jääskeläinen, A. S., Froidevaux, J., Hughes, M., Navi, P. (2012). Natural and artificial ageing of spruce wood as observed by FTIR-ATR and UVRR spectroscopy. Holzforschung, 66(2), 163-170.

12. Gupta, B. S., Jelle, B. P., Per Jostein, H., Rüther, P. (2011). Studies of wooden cladding materials degradation by spectroscopy. Proceedings of the Institution of Civil Engineers-Construction Materials, 164(6), 329-340."

13. Hon, D. N. S. (2007). Degradative effects of ultraviolet light and acid rain on wood surface quality. Wood and fiber science, 26(2), 185-191.

14. Hon, D.N.S., Chang, S.T. (1984). Surface degradation of wood by ultraviolet light. Journal of Polymer Science: Polymer Chemistry Edition, 22(9), 2227-2241.

15. Hon, D.N.S.; Minemura, N. (2001).Color and discoloration. In Wood and Cellulosic Chemistry; Hon, D.N.S., Shirashi, N., Eds.; Marcel Dekker: New York, NY, USA, pp. 385-442.

16. Lesar, B., Humar, M., Kržišnik, D., Thaler, N., Žlahtič, M. (2016). Performance of façade elements made of five different thermally modified wood species on model house in Ljubljana. In Proceedings of the World Conference on Timber Engineering, Vienna, Austria, 22-25 August 2016; ISBN 978390303900-1. Available online: http://wcte2016.conf.tuwien.ac.at/ (accessed on 15 October 2020).

17. Liu, R., Pang, X., Yang, Z. (2017). Measurement of three wood materials against weathering during long natural sunlight exposure. Measurement, 102, 179-185.

18. Liu, X. Y., Timar, M. C., Varodi, A. M., Sawyer, G. (2017). An investigation of accelerated temperature-induced ageing of four wood species: colour and FTIR. Wood Science and Technology, 51(2), 357-378.

19. Müller, U., Rätzsch, M., Schwanninger, M., Steiner, M., Zöbl, H. (2003). Yellowing and IR-changes of spruce wood as result of UV-irradiation. Journal of Photochemistry and Photobiology B: Biology, 69(2), 97-105.

20. Nemeth, R., Hill, C. A., Takats, P., Tolvaj, L. (2016). Chemical changes of wood during steaming measured by IR spectroscopy. Wood Material Science Engineering, 11(2), 95-101.

21. Pandey, K. K. (2005). A note on the influence of extractives on the photo-discoloration and photodegradation of wood. Polymer degradation and stability, 87(2), 375-379.

22. Pandey, K. K., Pitman, A. J. (2003). FTIR studies of the changes in wood chemistry following decay by brown-rot and white-rot fungi. International biodeterioration biodegradation, 52(3), 151-160. 
23. Reinprecht, L. (2016) Wood Deterioration, Protection and Maintenance; John Wiley Sons, Ltd.: Chichester, UK, p. 376. ISBN 978-1-119-10653-1.

24. Reinprecht, L., Mamoňová, M., Pánek, M., Kačík, F. (2018). The impact of natural and artificial weathering on the visual, colour and structural changes of seven tropical woods. European Journal of Wood and Wood Products, 76(1), 175-190.

25. Teacă, C. A., Roşu, D., Bodîrlău, R., Roşu, L. (2013). Structural changes in wood under artificial UV light irradiation determined by FTIR spectroscopy and color measurements-A brief review. BioResources, 8(1), 1478-1507.

26. Timar, M. C., Varodi, A. M., Hacibektasoglu, M., Campean, M. (2016). Color and FTIR analysis of chemical changes in beech wood (Fagus sylvatica L.) after light steaming and heat treatment in two different environments. BioResources, 11(4), 8325-8343.

27. Tolvaj, L., Faix, O. (1995). Artificial aging of wood monitored by drift spectroscopy and CIE Lab color measurements. Holzforschung, 49(5), 397-404.

28. Turkulin, H., Derbyshire, H., Miller, E. R. (2004). Investigations into the photodegradation of wood using microtensile testing. Holz als Roh-und Werkstoff, 62(4), 307-312.

29. Zor, M. ve Can, A. (2021). Shear Strength in Friction Welded Joint of Poplar Wood Impregnated with Copper-Based Wood Preservative, Maderas. Ciencia y tecnología (23):9, 1-8.

30. Zor, M., Can, A., Gardner, D.J. (2019). Surface characterization of weathered and heat-treated woodbased composites reinforced by styrene maleic anhydride. Colour Research and Application, 44(6), 1017-1023. 